\title{
Interactions between building information modelling and off-site manufacturing for productivity improvement
}

\begin{abstract}
Purpose- New methods have been introduced as revolutionary approaches in the construction industry, such as Off-Site Manufacturing (OSM) and Building Information Modelling (BIM). Although these approaches can provide many benefits, there are still barriers to meeting the expectations of improved construction productivity via their implementation. Hence, this paper aims to critically review the capabilities of OSM and BIM techniques, as well as their potential interactions, in productivity improvement.
\end{abstract}

Design/methodology/approach- A scoping review approach was adopted, where 100 peer-reviewed journal articles were collected to analyse the capabilities of OSM and BIM, as well as their potential interactions, in productivity improvement as assessed by key productivity indicators (KPrIs).

Findings- The results reveal seven BIM-based capabilities and six OSM-based capabilities, as well as 12 potential OSM-BIM interactions that have significant potential for satisfying KPrIs.

Originality/value- An integrated framework has also been developed to clarify and conceptualise the roles of OSM-BIM interactions in their designated KPrIs. The research has developed insightful and practical references for strategic planning and management in OSM-BIM-based projects.

Keywords Construction, Project Performance, Productivity, Capabilities, Integrated Framework, Interactions, OSM, BIM 


\section{Introduction}

Construction professionals have always searched for new methods to improve productivity. However, the selection of the most suitable and practical construction method remains a common challenge in construction performance (Ferrada \& Serpell, 2013). Traditionally, researchers have attempted to target productivity improvement through benchmarking the best practices with productivity indicators in construction projects (Arditi \& Mochtar, 2000; Cox, Issa, \& Ahrens, 2003; Enshassi, Kochendoerfer, \& Abed, 2013). Achieving success in the establishment of new technologies very much depends on the balance of the integration of the capabilities and potentials of the system against the fragmentation of the processes and parties involved in a project (Blayse \& Manley, 2004). The collaboration of all parties is key to performance enhancement and successful project delivery (Walker, 2018).

Building Information Modelling (BIM) is a new technique that has recently arisen in the construction industry worldwide, and operates at different stages of the life cycle of a project. BIM, through its visualisation and information-sharing abilities, enables stakeholders to combine designs and assess the outcomes during the early stages of a project (Ding, Zuo, Wu, \& Wang, 2015). Porwal and Hewage (2013) observed in their case study that BIM has been proven to improve the construction process through efficient coordination among the stakeholders and the provision of accurate information. In fact, many countries have actively promoted BIM technology. The United States (US) is believed to be one of the pioneering countries in the adoption of BIM, where the public sector and departments at different levels have established BIM programmes, roadmaps and standards (Cheng \& Lu, 2015). The United Kingdom (UK) government has the same approach to BIM and has even regulated the mandatory measure to use of BIM Level 2 on certain projects (Khosrowshahi \& Arayici, 2012; Ganah \& John, 2014). The mandatory use of BIM could bring increased competitiveness and productivity in the long run (Bryde et al., 2013). The potential of BIM to increase construction productivity and performance in the broader sense has been extended from buildings to infrastructure projects (Chong et al., 2016). The clarification of responsibilities, agreements and duties through BIM effectively contributes to project productivity (Azhar, 2011; Chong et al., 2017; Love, et al., 2011). Nevertheless, BIM is still evolving and its potential very much depends on certain factors, such as project size, team members' proficiency, the communication conditions among the project's members and external organisation-related factors (Barlish and Sollivan, 2012).

Off-Site Manufacturing (OSM) is a method in which components are produced via factory activities and then assembled and erected via on-site activities (Khalfan \& Maqsood, 2014). OSM has been defined as a technique for improving both quality and quantity in construction. OSM consistently demonstrates higher productivity improvement compared to traditional construction based on on-site activities only (Eastman $\&$ Sacks, 2008). It has also been introduced as the most influential agent in creating noticeable opportunities to improve the construction industry globally in future decades (SBEnrc, 2017).

In response to stakeholders and end users' expectations, the interactions between these new technologies have put on the agenda to optimise time, cost and quality, as the main aspects determining construction performance (Aliakbarlou et al., 2018). Although these new concepts can be applied to projects independently, some characteristics of each concept will cover the others via hybrid concepts to improve the stages of the project. For example, BIM is able to supplement certain other new technologies in achieving their objectives. BIM and Lean collaboration has been a widely highlighted outcome due to the integration of these concepts. Fifty-six interactions have been identified between BIM and Lean collaboration that improve the construction industry (Sacks et al., 2010). Another research study linked these two techniques under a mutual mission of waste reduction and efficiency growth, which generally 
created value in the construction sector ( $\mathrm{Bi}$ and Jia, 2016). It has been observed that an enriched model developed from BIM standards not only creates a platform for exact data exchange, through an effective communication line promoting Lean concepts (Hamdi and Leite, 2012; Sacks et al., 2009), but also improves prefabrication systems (Moghadam et al., 2012; Nawari, 2012). BIM is perceived to be one of the new technologies capable of accompanying OSM. BIM specifications seem to confer the ability to support and complement OSM and fulfil its potential once applied in practice.

Therefore, this paper aims to critically review the capabilities of both the OSM and BIM techniques, as well as their potential interactions in productivity improvement. A scoping review was adopted and the pathway was developed based on the question, 'which productivity indicators have the capacity to be affected so as to optimise project progress?', followed by another question: 'which indicators could be affected via the interaction of these two concepts and how do these capabilities overlap or work individually?' For this purpose, initially key productivity indicators (KPrIs) need to be developed through the literature review before investigating the effects of BIM and OSM on these indicators. This paper summarises how BIM can contribute to the improvement of project progress in an OSM-based project and vice versa. More specifically, the capabilities of BIM include highly accurate information regarding the specifications of components, visualisation of the project and site via a 3D model, a rapid informationsharing platform for early decision-making and optimum planning/scheduling, all of which can promote productivity in OSM-based construction projects.

\section{Literature Review}

Low productivity on construction sites has always been one of the stakeholders' main challenges in the construction industry. Many researchers have tried to develop various ideas to identify effective practices from different concepts and integrate these to promote the industry's status. The focus has been on improving customer satisfaction through product and process development, which required fostering of commitment between all parties involved in a project (Murray, 2003; Segerstedt and Olofsson, 2010). As such, KPrIs play a significant role in a construction project.

\subsection{KPrIs in construction}

Productivity indicators in construction projects can be referred to as the indicators by which the actual project progresses as the output will occur and be assessed by comparing it to the planning and scheduling template. Dozzi and AbouRizk (1993) stated that 'traditionally productivity has been defined as the ratio of input/output' (p. 1). Input refers to materials (\$), personnel (P-H), management and equipment (\$), while output refers to the production unit. The high costs of construction projects are in the nature of these projects. Thus, the minimum input expected to obtain the maximum output is deemed 'productivity achievement' (Huang et al, 2009). In this paper, the authors attempted to clarify the terms construction 'performance' and 'productivity'. The authors refer to the performance perspective as a broad overview, which can be followed by the productivity perspective in a narrow sense. This means that productivity is aligned with performance. Therefore, the productivity perspective may follow the performance perspective. However, Dozzi and AbouRizk (1993) believe that the term 'performance' can also be used instead of 'productivity'. Comin (2010, p.260) stated that 'Total Factor Productivity (TFP) is the portion of output not explained by the number of inputs used in production'. Thus, the production unit can be deemed as project progress in construction projects. 
There is a wide range of indicators impacting productivity that can be designated under the socio-economic conditions present in both developing and developed countries (Hasan et al., 2018). These indicators have been categorised into quantitative and qualitative indicators; quantitative indicators are those that are physically measurable and applicable by means of numbers, amounts and units, such as a report of costs, completion percentage, the amount of materials and the number of human resources, while qualitative performance indicators are those that are not easily and tangibly measurable. These indicators do not offer accurate data on a project's status, but describe a situation, such as a safety report (Cox et al., 2003). The conceptual framework below summarises the papers showing the categories and subcategories of productivity indicators in construction projects (Allmon et al., 2000; Arditi and Mochtar, 2000; Bassioni et al., 2004; Chan et al., 2004; Chan and Kumaraswamy, 1995; Chan, 2009; Cox et al., 2003; Diamantopoulos and Winklhofer, 2001; Dozzi and AbouRizk, 1993; Enshassi et al., 2013; Kapelko et al., 2015; Meng, 2012; Poirier et al., 2015; Takim and Akintoye, 2002). 


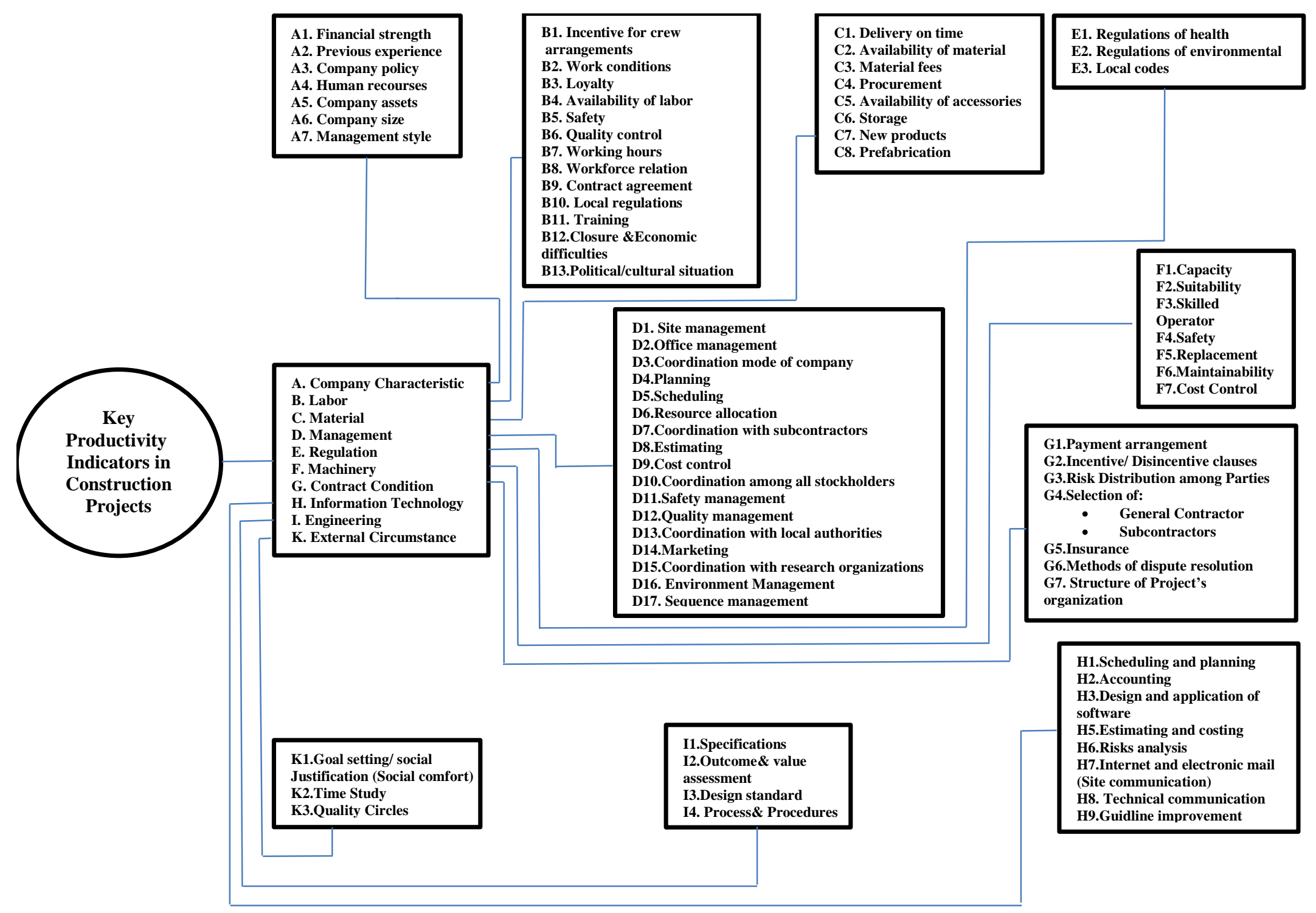

Figure 1. Conceptual framework of key productivity factors leveraging project success 


\subsection{BIM and the level of adoption}

BIM is the process of developing and applying a simulated model of the planning, designing, construction and operation of a building, which contains a collection of data and rich information on all the details relating to a project during its life cycle. BIM is a smart 3D CAD, automatically adaptable to any change and connected to a database that acts as a common source for all parties involved in the project.

BIM has moved into the areas of architecture, engineering and management. The level of BIM uptake is determined by the activities for which it was designed to be used. This determines the level of integration of practice and professionalism in a company using BIM. Thus, the uptake level varies from one company to another (Haron et al., 2010; Newton and Chileshe, 2012). Figure 2 presents the practices derived from BIM, with the centre of the figure showing the common applications of BIM. As can be seen, these include sequencing, clash detection, facility management, constructability assessment, estimation and measurement (Chong et al., 2014). The improvement of conflict management has been noted as a capability of BIM, as potential disputes can be better controlled (Charehzehi et al., 2017).

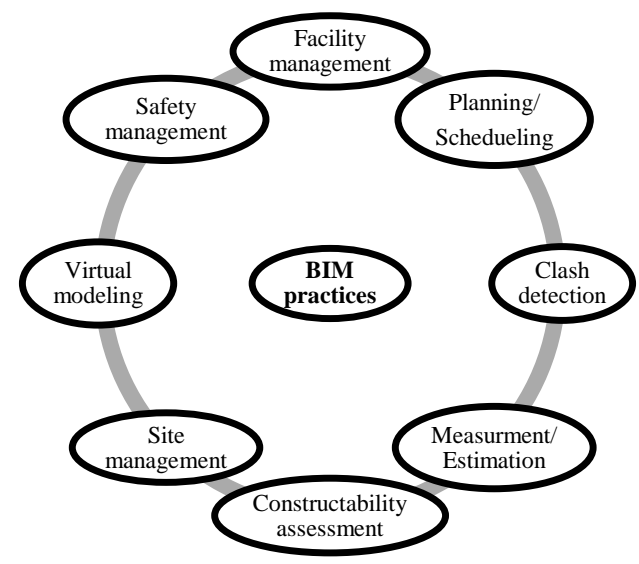

Figure 2. The potential practices of BIM in construction projects

\subsection{OSM and the level of adoption}

The OSM approach is a modern technique in which prefabricated construction components are merged and erected as an on-site activity. The components are produced off-site in a controlled manufacturing environment and then transported to and positioned on the construction site (Blismas, 2007). The severe lack of construction workers and material resources after the world wars of 1914-1918 and 1939-1945 opened the gate for the advent of OSM. Many terms have been considered for this concept (Vernikos et al., 2014), all of which, with a few variations in their applicability, have resulted in the OSM system that is now commonly used (Amanda et al., 2017).

An industry report prepared by Sustainable Built Environment National Research Centre (SBEnrc, 2017) declared the UK to be a pioneer in fostering and benefiting from OSM, which had resulted in a noticeable improvement in their construction programme, meaning that significant environmental, economic and social benefits have been achieved via OSM. The market in the Asia-Pacific, as the most demanding market 
for investment in OSM, has been calculated to amount to USD100 billion up until 2020. A report in 2012 showed that China had the largest market share (60\%), while the smallest market share belonged to Indonesia, at just 5\%. Japan and Australia shared 22\% and 7\% of this investment, respectively. It has been noted that the rate of growth of the OSM market in Australia will dramatically increase due to the high costs of both labour and importing manufactured components. Strengthening the internal market and fostering job opportunities in Australia may thus be another main reason for harnessing the OSM approach. Some obvious values arising from OSM are 'reduced risk of delay, reduced likelihood of variation, increased construction safety, more attraction to home buyers, greater return on equity, reduced material cost, less theft, vandalism, and damage of material' (SBEnrc, 2017, p.8-9). The costs of OSM-based projects that are not applicable to non-OSM projects have been arguably assumed to be a barrier to the uptake of the OSM approach (Blismas \& Wakefield, 2009). Certain extra costs have been seen to place pressure on projects due to the lack of systematic uptake, highlighting which stage and how the uptake of OSM should be considered. The uptake level may vary in between projects based on the characteristics and situation of the project (Blismas \& Wakefield, 2009). Although many researchers have identified significant benefits from the utilisation of OSM, there are still barriers to embracing the OSM approach and reaping these benefits in Australia (Wynn et al., 2013). Every action is crucial to support the decision regarding OSM uptake via offering supplementary abilities in order to promote productivity and efficiency (Blismas \& Wakefield, 2009).

\subsection{The concept of interactions}

A combination of techniques may sometimes increase the capabilities of both techniques. One proposed solution to the problem of cost overrun in the construction industry is the concomitant application of Lean and linear programming strategies as an interacting measure (Gade, 2016). BIM, as an interactive technique, has been used to influence the industry by providing a collaborative approach and an information-sharing platform. For instance, the concepts of Lean principles interact with BIM in both positive and negative ways (Sacks et al., 2010). An enriched BIM model can effectively support OSM projects at different uptake levels, subject to capturing suitable readable data available in a BIM model and exchanging these with other stakeholders (Nawari, 2012). Wynn et al. (2013) believe that construction efficiency can be promoted by an OSM-oriented process that is supported by IT solutions such as BIM and Acconex.

\subsubsection{BIM and OSM}

OSM, as an advanced technology, holds tremendous potential to interact with BIM to contribute to improvements in the construction industry (Goulding et al., 2012). Faster progress, quality and cost optimisation and minimisation of work corrections on site; or in the broader sense, a more sustainable site, arise from the integration of off-site produced units in a construction project (Arif et al., 2012; Khalfan and Maqsood, 2014). Previous studies, however limited, have briefly discussed the potential benefits of BIM in OSM. For example, BIM has been recognised as having the potential to link design, manufacturing and construction through a workshop in relation to OSM (Goulding et al., 2012). Vernikos et al. (2014, p. 152) interviewed 12 leading BIM experts and innovation directors and found that BIM can improve OSM through 'configuration and interface management; information data flow; project management and delivery; procurement and contracts'. Nawari (2012) stated that an enriched BIM model can be effectively used by not only manufacturers to produce prefabricated components, but also by users needing to capture

all related data from the BIM model, which will improve building processes in OSM-based projects. Ezcan 
et al., (2013) explained that how BIM can cover some of the weaknesses of OSM that have been reported in the literature. Amanda et al. (2017) revealed far greater benefits of BIM in OSM than in traditional construction techniques by considering a range of parameters, such as time, cost, quality, sustainability, market culture, poor integration and safety, among others.

The current research proposes an interaction between OSM and BIM through an integrated framework for productivity improvement. As an example, precise information on the details of a component, including its dimensions and assembly descriptions, visible via BIM can assist fabricators to better position the component. In order to exploit this capability, some researchers believe that design data are effectively transferable into the prefabrication process in a factory environment via BIM's capacity to offer exact digital specifications, although others have stated that despite the BIM specifications, the success of new concepts depends on organisational strategy (Vernikos et al., 2014) and project governance functions (Hjelmbrekke et al., 2017).

\section{Review Approach}

The approach taken for the scoping review was to retrieve the necessary data from the literature. This review approach consolidates the evidence on the research variables on the basis of their potential links or synergies (Pham et al., 2014). This is particularly useful for new topics and dealing with a lack of comprehensive literature (Peters et al., 2015). Figure 3 shows the overall processes, along with the main contents, that shaped the scoping approach. Through the literature review, six categories were identified for improving construction productivity either individually or synergistically: resources, management, engineering, procurement and contracts, information technology and sustainability. The second stage involved searching the channels of evidence, including the collection and filtration of the type of literature. Relevant papers were identified by keyword searches of Google Scholar and library databases, and their relevance was assessed by examining their abstracts was. The keywords used in the searches were construction productivity growth/Improvement, BIM capabilities, OSM capabilities, BIM in construction, OSM in construction and BIM-OSM contribution. In detail, the first step of the selection process retrieved articles relating to performance and productivity in construction. Thirty-four papers were identified, and following assessment, 27 were retained based on the required productivity indicators. Next, these papers were scanned to identify a clear understanding of the definition of BIM and OSM and their capabilities. Twenty OSMrelated papers and 57 BIM-related papers were screened, with 16 and 50 retained, respectively. The identification process was followed by an in-depth search on the current state of BIM-OSM interactions, from which seven relevant papers were retrieved and analysed. The screening process was necessary to obtain and analyse reliable and accurate sources of materials for the literature review. The research questions were then developed, asking how BIM, OSM and BIM-OSM overlaps and interactions may improve KPrIs. Finally, 100 journal articles covering the scope of these techniques were selected. 


\begin{tabular}{|c|c|c|c|c|c|}
\hline \multicolumn{6}{|c|}{$\begin{array}{l}\text { Step 1: Scope clarification } \\
\text { Aim: To prepare a comprehension of the current state of BIM-OSM overlaps for improved KPIs }\end{array}$} \\
\hline \multicolumn{6}{|c|}{ Key Concepts for Investigation } \\
\hline No & Categories & $\begin{array}{l}\text { BIM-related } \\
\text { Publications }\end{array}$ & $\begin{array}{l}\text { OSM-related } \\
\text { Publications }\end{array}$ & $\begin{array}{l}\text { BIM-OSM } \\
\text { related } \\
\text { Publications }\end{array}$ & $\begin{array}{l}\text { Construction } \\
\text { Productivity/Perfor } \\
\text { mance publication }\end{array}$ \\
\hline 1 & Resources & \multirow{5}{*}{$\begin{array}{l}\text { Did the papers } \\
\text { address KPIs } \\
\text { improvements? }\end{array}$} & \multirow{5}{*}{$\begin{array}{l}\text { Did the papers } \\
\text { address KPIs } \\
\text { improvements? }\end{array}$} & \multirow{5}{*}{$\begin{array}{l}\text { Did the papers } \\
\text { address KPIs } \\
\text { improvements? }\end{array}$} & \multirow{5}{*}{$\begin{array}{l}\text { Did the papers } \\
\text { address KPIs in } \\
\text { construction? }\end{array}$} \\
\hline 2 & Management & & & & \\
\hline 3 & Engineering & & & & \\
\hline 4 & Procurement and contract & & & & \\
\hline 5 & Information Technology & & & & \\
\hline 6 & Sustainability & & & & \\
\hline
\end{tabular}

\begin{tabular}{|l|l|l|}
\hline \multicolumn{2}{|c|}{ Step 2: Searching channels for the evidence } \\
\hline Stages & Resources & Key words \\
\hline Collection & Google scholar search & Construction productivity growth/Improvement \\
& Article journals database search & BIM capabilities \\
& & OSM capabilities \\
Filtration & & BIM-OSM contribution \\
& & BIM in construction \\
& & OSM in construction \\
\hline
\end{tabular}

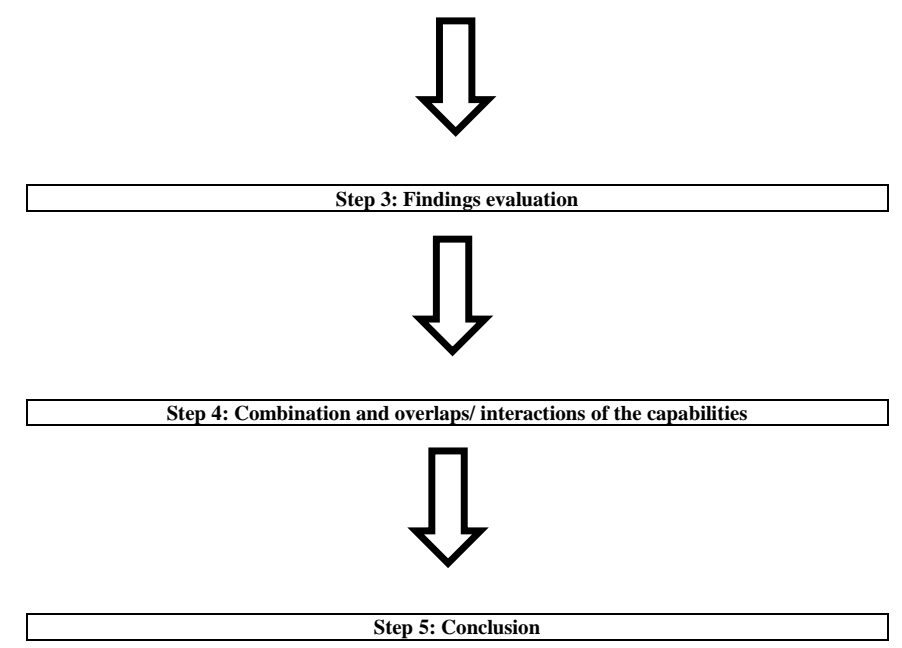

Figure 3. The selection process for the literature review

\section{Data Analysis and Findings}

Table 1a shows the four research categories investigated in detail; namely, construction productivity/performance, BIM in construction, OSM in construction and BIM-OSM interaction. Productivity/performance growth and the indicators used in construction projects were discussed from the first category of papers identified. The role of BIM and OSM and their capabilities as standalone improvement approaches were described from the second and the third categories, while the interactions between BIM and OSM were investigated in the last category of papers. Table $1 \mathrm{~b}$ summarises the number of articles reviewed in each of the research areas. 
Table 1a. Peer-reviewed publications in the proposed research areas

\begin{tabular}{|c|c|c|c|c|c|}
\hline No & Academic researches & $\begin{array}{l}\text { Construction performance/ } \\
\text { Productivity publications }\end{array}$ & $\begin{array}{l}\text { BIM in construction } \\
\text { publications }\end{array}$ & $\begin{array}{l}\text { OSM in construction } \\
\text { publications }\end{array}$ & $\begin{array}{l}\text { BIM-OSM Interaction } \\
\text { confirming publications }\end{array}$ \\
\hline 1. & Amanda et al. (2017) & & & & $\mathrm{X}$ \\
\hline 2. & Ahmad and Thanheem (2018) & & $\mathrm{X}$ & & \\
\hline 3. & Aliakbarlou (2018) & $\mathrm{X}$ & & & \\
\hline 4. & Allmon et al. (2000) & $\mathrm{X}$ & & & \\
\hline 5. & Arashpour et al. (2015) & & & $\mathrm{X}$ & \\
\hline 6. & Arditi and Mochtar (2000) & $\mathrm{X}$ & & & \\
\hline 7. & Arif et al. (2012) & $\mathrm{X}$ & & & \\
\hline 8. & Azhar (2011) & & $\mathrm{X}$ & & \\
\hline 9. & Azhar et al. (2012) & & $\mathrm{X}$ & & \\
\hline 10. & Azhar et al. (2009) & & $\mathrm{X}$ & & \\
\hline 11. & Bank et al. (2010) & & $\mathrm{X}$ & & \\
\hline 12. & Barati et al. (2013) & & $\mathrm{X}$ & & \\
\hline 13. & Barlish and Sullivan (2012) & & $\mathrm{X}$ & & \\
\hline 14. & Bassioni et al. (2004) & $\mathrm{X}$ & & & \\
\hline 15. & Bi and Jia (2016) & & $\mathrm{X}$ & & \\
\hline 16. & Blayse and Manley (2004) & $\mathrm{X}$ & & & \\
\hline 17. & Blismas (2007) & & & $\mathrm{X}$ & \\
\hline 18. & Blismas et al. (2006) & & & $\mathrm{X}$ & \\
\hline 19. & Blismas and Wakefield (2009) & & & $\mathrm{X}$ & \\
\hline 20. & Blismas et al. (2005) & & $\mathrm{X}$ & & \\
\hline 21. & Bryde et al. (2013) & & & $\mathrm{X}$ & \\
\hline 22. & Boyd et al. (2012) & & & $\mathrm{X}$ & \\
\hline 23. & Chan et al. (2004) & $\mathrm{X}$ & & & \\
\hline 24. & Chan and Kumaraswamy (1995) & $\mathrm{X}$ & & & \\
\hline 25. & Chan (2009) & $\mathrm{X}$ & & & \\
\hline 26. & Charehzehi et al. (2017) & & $\mathrm{X}$ & & \\
\hline 27. & Cheng and $\mathrm{Lu}(2015)$ & & & $\mathrm{X}$ & \\
\hline 28. & Chen and $\mathrm{Lu}(2014)$ & & $\mathrm{X}$ & & \\
\hline 29. & Chong et al. (2017) & & $\mathrm{X}$ & & \\
\hline 30. & Chong et al. (2014) & & $\mathrm{X}$ & & \\
\hline 31. & Chong et al. (2016) & & & & \\
\hline 32. & Cirbini et al. (2015) & & $\mathrm{X}$ & & \\
\hline 33. & Cox et al. (2003) & $\mathrm{X}$ & & & \\
\hline 34. & Diamantopoulos and Winklhofer (2001) & $\mathrm{X}$ & & & \\
\hline 35. & Ding et al. (2014) & & $\mathrm{X}$ & & \\
\hline 36. & Ding et al. (2015) & & $\mathrm{X}$ & & \\
\hline 37. & Dozzi and AbouRizk (1993) & $\mathrm{X}$ & & & \\
\hline 38. & Eastman and Sacks (2008) & $\mathrm{X}$ & & & \\
\hline 39. & Murry (2003) & $\mathrm{X}$ & & & \\
\hline 40. & Elnaas et al. (2014) & $\mathrm{X}$ & & & \\
\hline 41. & Enshassi et al. (2013) & $\mathrm{X}$ & & & \\
\hline 42. & Ezcan et al. (2013) & & & & $\mathrm{X}$ \\
\hline 43. & Ferrada and Serpell (2013) & $\mathrm{X}$ & & & \\
\hline 44. & Forgues et al. (2012) & & $\mathrm{X}$ & & \\
\hline 45. & Gade (2016) & $\mathrm{X}$ & & & \\
\hline 46. & Ganah and John (2014) & & & $\mathrm{X}$ & \\
\hline 47. & Ghazali, W., \& Irsyad, W. A. (2016) & & $\mathrm{X}$ & & \\
\hline 48. & Goulding et al. (2012) & & & & $\mathrm{X}$ \\
\hline 49. & Goulding et al. (2015) & & & $\mathrm{X}$ & \\
\hline 50. & Hamdi and Leite (2012) & & $\mathrm{X}$ & & \\
\hline 51. & Haron et al. (2010) & & $\mathrm{X}$ & & \\
\hline 52. & Hasan et al. (2018) & $\mathrm{X}$ & & & \\
\hline 53. & Hergunsell (2011) & $\mathrm{X}$ & & & \\
\hline 54. & Haung (2009) & $\mathrm{X}$ & & & \\
\hline 55. & Hjelmbrekke et al. (2017) & & & & \\
\hline 56. & Irizarry et al. (2013) & & $\mathrm{X}$ & & \\
\hline 57. & Kang et al. (2007) & & $\mathrm{X}$ & & \\
\hline 58. & Kapelko et al. (2015) & $\mathrm{X}$ & & & \\
\hline 59. & Khalfan and Maqsood (2014) & & & $\mathrm{X}$ & \\
\hline 60. & Khoshnava et al. (2012) & & & & \\
\hline 61. & Khosrowshani and Arayici (2012) & & & $\mathrm{X}$ & \\
\hline 62. & Lee et al. (2015) & & $\mathrm{X}$ & & \\
\hline 63. & Lessing et al. (2005) & & & & \\
\hline 64. & Li et al. (2014) & & $\mathrm{X}$ & & \\
\hline 65. & Love et al. (2011) & & $\mathrm{X}$ & & \\
\hline 66. & Lu and Korman (2010) & & & & $\mathrm{X}$ \\
\hline 67. & Lu et al. (2017) & & $\mathrm{X}$ & & \\
\hline 68. & Meiling et al. (2012) & & & $\mathrm{X}$ & \\
\hline 69. & Meng (2012) & $\mathrm{X}$ & & & \\
\hline 70. & Moghadam et al. (2012) & & $\mathrm{X}$ & & \\
\hline 71. & Nawari (2012) & & & & $\mathrm{X}$ \\
\hline 72. & Newton and Chileshe (2012) & & $\mathrm{X}$ & & \\
\hline 73. & Olofsson et al. (2007) & & $\mathrm{X}$ & & \\
\hline 74. & Pan et al. (2012) & & & $\mathrm{X}$ & \\
\hline 75. & Park et al. (2017) & & $\mathrm{X}$ & & \\
\hline
\end{tabular}




\begin{tabular}{|c|c|c|c|c|c|}
\hline 76. & Pasquire and Connolly (2002) & & & $\mathrm{X}$ & \\
\hline 77. & Pellinen (2016) & & $\mathrm{X}$ & & \\
\hline 78. & Poririer et al. (2015) & $\mathrm{X}$ & & & \\
\hline 79. & Popov et al. (2010) & & $\mathrm{X}$ & & \\
\hline 80. & Porwal and Hewage (2013) & & & $\mathrm{X}$ & \\
\hline 81. & Sacks et al. (2010) & $\mathrm{X}$ & & & \\
\hline 82. & Sacks et al. (2009) & $\mathrm{x}$ & & & \\
\hline 83. & SBEnrc (2017) & & & $\mathrm{X}$ & \\
\hline 84. & Shin et al. (2016) & & & $\mathrm{X}$ & \\
\hline 85. & Segerstedt and Olofsson (2010) & $\mathrm{X}$ & & & \\
\hline 86. & Smith (2014) & & $\mathrm{X}$ & & \\
\hline 87. & Succar (2009) & & $\mathrm{x}$ & & \\
\hline 88. & Sulankivi et al. (2010) & $\mathrm{X}$ & & & \\
\hline 89. & Takim and Akintoye (2002) & $\mathrm{X}$ & & & \\
\hline 90. & Trani et al. (2015) & & $\mathrm{X}$ & & \\
\hline 91. & Vernikos et al. (2014) & & & & $\mathrm{X}$ \\
\hline 92. & Walker (2018) & $\mathrm{X}$ & & & \\
\hline 93. & Wang et al. (2015) & & $\mathrm{X}$ & & \\
\hline 94. & Wang and Love (2012) & & $\mathrm{x}$ & & \\
\hline 95. & Wang and Chong (2016) & & & & \\
\hline 96. & Wong and Fan (2013) & & $\mathrm{X}$ & & \\
\hline 97. & Wong and Kuan (2014) & & $\mathrm{x}$ & & \\
\hline 98. & Wynn et al. (2013) & & & & $\mathrm{X}$ \\
\hline 99. & Zhang et al. (2010) & & $\mathrm{X}$ & & \\
\hline 100. & Zhang et al. (2013) & & $\mathrm{x}$ & & \\
\hline
\end{tabular}

Table 1b. Summary of the papers on BIM, OSM and performance

\begin{tabular}{|l|l|}
\hline Research categories & Number of the papers \\
\hline BIM specification and capabilities in construction & 50 \\
\hline OSM specifications and capabilities in construction & 16 \\
\hline BIM-OSM interactions confirming papers & 7 \\
\hline Construction performance/productivity & 27 \\
\hline Total papers & 100 \\
\hline
\end{tabular}

\subsection{The standalone OSM capabilities/functions for KPrIs}

The table below summarises the indicators that can be improved using standalone OSM techniques, and reflects the relevant KPrIs in Figure1. The following sections discuss the ways in which the nominated KPrIs can be improved under OSM functionalities.

Table 2. Nominated KPrIs affected by OSM functions

\begin{tabular}{|l|c|c|c|}
\hline $\begin{array}{c}\text { The nominated KPrIs } \\
\text { variables from Figure 1 }\end{array}$ & $\begin{array}{c}\text { The KPrIs' } \\
\text { signifier }\end{array}$ & $\begin{array}{c}\text { Number of sources of evidence } \\
\text { contributing to effect on the } \\
\text { variables }\end{array}$ & $\begin{array}{c}\text { Sources contributing to the justification of } \\
\text { interactions }\end{array}$ \\
\hline Planning and scheduling & D4\&D5 & 3 & $\begin{array}{c}\text { Elnaas et al. (2014); Lessing et al. (2005); } \\
\text { SBEnrc (2017) }\end{array}$ \\
\hline Safety & D11 & 2 & Blismas et al. (2005); SBEnrc (2017) \\
\hline Marketing & D14 & 2 & Pan et al. (2012); SBEnrc (2017) \\
\hline Cost control & D9 & 2 & Pasquire\& Connolly (2002); SBEnrc (2017) \\
\hline Site management & D1 & 2 & Arashpour et al. (2015); Meiling et al. (2012) \\
\hline Sustainability & D9/D16/K1 & 3 & $\begin{array}{c}\text { Abanda et al. (2017); SBEnrc (2017); Boyd et } \\
\text { al. (2012) }\end{array}$ \\
\hline
\end{tabular}

\subsubsection{Planning and scheduling}

Low-quality construction may result in rework or modifications. As manufactured components are simply attachable in construction sites, rapid erection will shorten the construction process (SBEnrc, 2017). Also, quality control may be more feasible and precise in a controlled environment, due to better accessibility to 
the tools required for quality measurement in order to comply with specifications (Elnaas et al., 2014). Thus, the chances of any rework or correction being required on the site can be minimised. In addition, the construction process can be simplified if it follows a smoother plan and schedule, which leads to quicker completion. Off-Site Manufacturing has rectified many problems in the construction industry, as well as improving planning, scheduling and control, both off-site and on-site activities. These optimisations are beneficial and productive in OSM-based construction projects (Lessing et al., 2005) compared to non-OSMbased projects. Therefore, planning and scheduling of services, such as supply, transportation and human resources management are able to be improved in OSM-based projects. 


\subsubsection{Safety}

Occupational health and safety regulations are more easily observed in a controlled working environment, such as a factory (Blismas et al., 2005). Injuries arising from falls and collisions are more avoidable in these conditions, as the necessary safety considerations are easier to meet (SBEnrc, 2017). Also, it is logical that the reduced on-site activities required in an OSM-based project will result in fewer construction crew members being required on the site, thereby reducing the likelihood of injuries.

\subsubsection{Marketing}

Marketing is improved by attracting more clients/stakeholders. To be more specific, promising a quicker construction period, along with high-quality products, is attractive to homebuyers, who assume that earlier construction completion and settlement in their homes will help them pay less rent and save more. This is also attractive to investors, in that they will expect to achieve a quicker return on their equity, while more rapid completion results in a project being sold more quickly. Consequently, more rapid cash flow and capital return and re-investment will occur, which is especially important for commercial projects (SBEnrc, 2017; Pan et al., 2012).

\subsubsection{Cost control}

The 24-hour availability of materials in the site store prevents delays due to the ordering process. The longer the completion, the greater the overhead costs. On the other hand, not only will the costs of multiple orders be eliminated, but also the purchase of a large volume of materials at lower prices is possible. The cost of waste management is another issue that is avoidable once waste and reuse-related issues are handled by the factories. For example, no dumping costs are imposed (SBEnrc, 2017). In a controlled environment, the chance of material protection is maximised, resulting in an economical material cost due to material storage optimisation (Pasquire and Connolly, 2002). In other words, any possibility of material damage arising from weather conditions and the probability of vandalism, theft and mistakes as a result of human handling are minimised.

\subsubsection{Site management}

Reducing on-site construction activity and reducing congestion in these activities also reduces human errors, resulting in better and more efficient site management (Arashpour et al., 2015; Meiling et al., 2012).

\subsubsection{Sustainability}

More controllable production reduces the chance of material wastage. This contributes to environmental sustainability (less waste) and economic sustainability (reduced costs due to less material usage). Energy consumption is also more efficient due to more controllable on-site equipment and energy savings resulting from less trade and activity disruption (Abanda et al., 2017). Safety considerations are promoted in a factory environment. Furthermore, workers can be provided with a comfortable environment, as they do not work in severe weather conditions. This is associated with social sustainability (SBEnrc, 2017). Each of these sustainability factors comply with the 'people' principles of OSM (Boyd et al., 2012). 


\subsection{The standalone BIM capabilities/functions for KPrIs}

This section presents the KPrIs that contribute to improving a project via standalone BIM functionalities. Table 3 presents the nominated KPrIs, as shown in Figure 1.

Table 3. Nominated KPrIs affected by BIM functions

\begin{tabular}{|c|c|c|c|}
\hline $\begin{array}{l}\text { The nominated KPrIs from } \\
\text { Fig1 }\end{array}$ & $\begin{array}{l}\text { The KPrIs' } \\
\text { signifier }\end{array}$ & $\begin{array}{c}\text { Number of sources of } \\
\text { evidence contributing to effect } \\
\text { on the variables }\end{array}$ & $\begin{array}{l}\text { Sources contributing to the justification of } \\
\text { interactions }\end{array}$ \\
\hline $\begin{array}{l}\text { Sequence /Process } \\
\text { management }\end{array}$ & D17 & 2 & Chen \& Luo (2014); Wang \& Love (2012) \\
\hline $\begin{array}{l}\text { Site allocation \& } \\
\text { accessibility }\end{array}$ & D1 & 2 & Hergunsel (2011); Vernikos et al. (2014) \\
\hline Planning\& Scheduling & D4\&D5 & 5 & $\begin{array}{c}\text { Barati et al. (2013); L.Ding et al. (2014); } \\
\text { Kang et al. (2007); Hergunsel (2011); } \\
\text { Li et al. (2014) }\end{array}$ \\
\hline Safety & D11 & 3 & $\begin{array}{l}\text { Chen \& Luo ( 2014); Khoshnava et al. (2012); } \\
\text { Ghazali\& Irsyad (2016); Sulankivi et al. (2010) }\end{array}$ \\
\hline Social Sustainability & K1 & 3 & $\begin{array}{c}\text { Ciribini et al. (2015); Wong \& Fan (2013); } \\
\text { Eastman \& Sacks (2008) }\end{array}$ \\
\hline Economic Sustainability & D9, C3\& F7 & 3 & $\begin{array}{c}\text { Wong \& Fan (2013); Azhar et al. (2009); Ahmad } \\
\text { and Thaheem (2018) }\end{array}$ \\
\hline Environment Sustainability & D16 & 2 & $\begin{array}{c}\text { Wong \& Fan (2013); } \\
\text { Lu et al. (2017) }\end{array}$ \\
\hline Interface management & D10\&D7 & 2 & Smith (2014); Olofsson et al. (2007) \\
\hline Procurement\& contract & G7 & 1 & Sacks et al. ( 2010) \\
\hline Information data & $\mathrm{H} 3,5,8,9 \& \mathrm{D} 10$ & 2 & Hamdi \& Leite (2012); Succar (2009) \\
\hline Value engineering & $\mathrm{I} 2$ & 2 & Park et al. (2017); Shin et al.(2016) \\
\hline Concurrent engineering & I4 & 2 & Pellinen (2016); Succar (2009) \\
\hline
\end{tabular}

\subsubsection{Sequence/process management}

Under the BIM approach, information-sharing between stakeholders links all the parties involved in a project, including the designer and the contractor, in a virtual 3D model with BIM management tools revealing all the related details. All parties are able to communicate easily to clarify any ambiguities or confusion (Chen \& Luo, 2014; Wang \& Love, 2012).

\subsubsection{Site allocation and accessibility}

The virtual site space created by BIM gives a good understanding of the 'site logistic plan' (Hergunsel, 2011). This is enables the effective organisation of the use of every location on the site in terms of the optimum layout of temporary offices, material stock, siting equipment and plant, among others (Vernikos et al., 2014).

\subsubsection{Planning and scheduling}

Effective identification of potential problems affecting project planning and scheduling is possible via a 3D BIM model, as all parties involved in a project are linked through working on the same model at the same time and exchanging relevant information (Barati et al,. 2013; Ding et al., 2014; Kang et al,. 2007). The application of the critical path method (CPM) and line of balance improve scheduling in BIM (Hergunsel, 2011).Through BIM, optimum resource management, which plays a significant role in cost control, is 
achievable. Therefore, scheduling can be improved via BIM (Li et al., 2014). This can be observed in both general planning/scheduling and re-planning/re-scheduling.

\subsubsection{Safety}

When site activities are better organised there are fewer the incidents resulting from site disruption. Through the virtual site environment model offered by BIM, safety considerations are more observable through a 'dynamic safety analysis' (Chen \& Luo, 2014); in particular, modelling of crane operation via BIM for site accessibility (Khoshnava et al., 2012), for materials transfers, plant operations and equipment movement, all of which will improve safety management. A 4D-BIM model provides an optimum site layout and more effective safety plans (Sulankivi et al., 2010), which can be 'a starting point for safety planning and communication' (Azhar et al., 2012, p .83).

\subsubsection{Social sustainability}

The 3D model offered in the BIM system enables designers to invite clients to review and impose any probable changes to a project to satisfy their needs and bidding offers. Feedback from clients is received before the commencement of construction, which not only prevents delay but also saves money, because any changes requested after construction begins may be costly (Ciribini et al., 2015). The increased safety offered via BIM can be considered as social sustainability, as workers are in a safer environment. This can also be considered as a social factors in workers' lives (Wong \& Fan, 2013), in that social sustainability focuses on people's convenience (Eastman \& Sacks, 2008).

\subsubsection{Economic sustainability}

Through the virtual model offered by BIM, design and construction management can be streamlined and improved (Wong \& Fan, 2013). To achieve this, the best decisions must be made for a project. For example, accurate information about the materials required minimises budget waste arising from the purchase of superfluous materials. The possibility of safety alerts also minimises the chances of compensation payouts being necessary due to falls and collisions. Azhar et al. (2009) stated that BIM returns $634-1633 \%$ of the initial investment. This confirms the satisfaction of economic sustainability considerations. Ahmad and Thaheem (2018) also highlighted the economic sustainability achieved in building energy consumption when BIM was implemented.

\subsubsection{Environment sustainability}

Materials are not wasted once there is no requirement for construction correction. More organised sites result in more efficient and effective activities, saving material and energy (Wong \& Fan, 2013). In fact, the optimisation of energy and material consumption achieved via BIM implementation can protect the natural environment and reflects both economic and environmental sustainability ( $\mathrm{Lu}$ et al., 2017).

\subsubsection{Interface management}

The ability to exchange readable data, subject to a compatible format, between the parties involved promotes a professional interface and effective linking between stakeholders (Smith, 2014). An informative link between the plumbing, electrical and mechanical systems is a constructive collaboration on construction sites. The conflicting activities of different teams sometimes affect each team, leading to the 
need for rework. This problem is rectifiable by BIM (Olofsson et al., 2007), which offers interface management possibilities.

\subsubsection{Procurement and contracts}

Lack of a procurement system and contracts suitable for BIM implementation is a barrier to achieving the full benefits from the adoption of BIM, which offers reforms on both the procurement and contract sides. The nature of information-sharing in the BIM environment specifies every action required by all parties involved in a project (Sacks et al., 2010). The definition of any likely required provision can be clearly given in the contract once the commitments of each party are specified. The party responsible for any defects or required actions is observable if the activities are monitored and traced via the BIM environment, which prevents disputes and contract complexity.

\subsubsection{Information data flow through virtual model quality and data richness}

In addition to a quality virtual model generating accurate information, a rapid line of communication for the exchange of data is provided by the BIM model (Hamdi and Leite, 2012). This removes any doubts regarding the requested specification of materials and elements and their integrity. Moreover, this function is also able to bridge the divide between academia and industry to allow further improvement of BIM guidelines as it is being practised.

\subsubsection{Value engineering}

A BIM-based value engineering (VE) idea bank enables stakeholders achieve rapid data retrieval from past experience at the idea generation phase (Park et al., 2017). Furthermore, the nature of this informationsharing platform links the stakeholders to each other in order to assess the consequences of a design or apply alternatives. In other words, an assessment of the feasibility of every change in terms of technical and cost factors is possible immediately via this smart virtual model, as the other parts of the model automatically update themselves with the changes. Under the VE process, the virtual model can return to the baseline by an undo function, with no money, energy or time being spent in reality. This confirms the sustainability aspects of a BIM-based VE (Shin et al., 2016).

\subsubsection{Concurrent engineering}

The theme of concurrent engineering can be clearly seen in BIM if there are the opportunities to fast-track activities or carry them out in parallel (Pellinen, 2016; Succar, 2009). As an example, the process of reviewing and confirming the designs, in terms of executive technical requirements, can be shortened by combining the models virtually (reviewing processes at the same time) rather than handing over the models sequentially and undertaking a paper-based model evaluation.

\subsection{The interaction of BIM and OSM for KPrIs}

Table 4 presents the potential OSM-BIM interactions. It justifies how these interactions occur and improve KPrIs once both techniques are applied simultaneously. The KPrIs to be improved are listed in the left column. The next column presents the relevant KPrIs from Figure 1, while the third column presents the sub-sections explaining OSM-BIM interactions. Lastly, the fourth column reveals the sources contributing to the justification of the OSM-BIM interactions. 
Table 4. A summary addressing the improvements achieved via OSM-BIM interactions

\begin{tabular}{|c|c|c|c|}
\hline $\begin{array}{l}\text { The nominated KPrIs for } \\
\text { improvement from Figure } 1\end{array}$ & $\begin{array}{l}\text { The KPrIs' } \\
\text { signifier }\end{array}$ & $\begin{array}{c}\text { The interactions descriptions } \\
\text { No via OSM-BIM } \\
\text { implementation }\end{array}$ & $\begin{array}{l}\text { Sources contributing to the justification of } \\
\text { interactions }\end{array}$ \\
\hline Sequence/Process management & D17 & Interaction 4.3 .1 & Lu and Korman (2010); Irizarry et al. (2013) \\
\hline Site allocation \& accessibility & D1 & Interaction 4.3 .2 & Vernikos et al. (2014); Trani et al. (2015) \\
\hline Planning\& Scheduling & D4\&D5 & Interaction 4.3 .3 & Bank et al. (2010) \\
\hline Safety & D11 & Interaction 4.4 .4 & $\begin{array}{c}\text { Zhang et al. (2013); Irizarry et al. (2013); } \\
\text { Zhang et al. (2010) }\end{array}$ \\
\hline Social Sustainability & K1 & Interaction 4.4 .5 & Wong \& Fan (2013) \\
\hline Economic Sustainability & D9, C3\& F7 & Interaction 4.4.6 & Wang\& Chong (2016) \\
\hline Environment Sustainability & D16 & Interaction 4.4 .7 & $\begin{array}{l}\text { Wang\& Chong (2016); } \\
\text { Wong \& Kuan (2014) }\end{array}$ \\
\hline Interface management & D10\&D7 & Interaction 4.4 .8 & Smith (2014) \\
\hline Procurement\& contract & G7 & Interaction 4.4 .9 & Barlish \& Sullivan (2012) \\
\hline $\begin{array}{l}\text { Information flow via virtual model } \\
\text { quality\& data Richness }\end{array}$ & $\mathrm{H} 3,5,8,9 \& \mathrm{D} 10$ & Interaction 4.4 .10 & $\begin{array}{l}\text { Haron et al. (2010); Ezcan et al (2013); Lee et al. } \\
\text { (2015); Popov et al. (2010); Sacks et al. (2010) }\end{array}$ \\
\hline Value engineering & $\mathrm{I} 2$ & Interaction 4.4 .11 & Forgues et al. (2012) \\
\hline Concurrent engineering & I4 & Interaction 4.4 .12 & Goulding et al. (2015) \\
\hline
\end{tabular}

The following sections discuss how these two techniques may interact constructively throughout a project.

\subsubsection{Sequence/process management}

The information-sharing capability in BIM will remove the issue of fragmentation between the different parties involved in a project (Lu and Korman, 2010). The sequences of OSM-based projects include design, order, component production, transfer and the installation process. As has been explained, BIM is capable of improving construction supply chain management through an integration process. The effective monitoring of resources is possible by linking and visually representing the process (Irizarry et al., 2013). As Irizarry et al., (2013, p.241) claimed, providing the digital geographic information of a construction site enables experts to sequentially keep track of the 'flow of materials, availability of resources, and map of the respective supply chains'. The manufactured components can also be deemed as the material in OSMbased projects. This optimises the identification of manufactured components at the stocking and dispatching stages.

\subsubsection{Site allocation and accessibility}

The virtual visualisation of objects provides the contractor a rapid and improved visual evaluation when comparing the planned and actual specifications and allows easier identification of any failure in the arrival of components. Thus, the placement of faulty and sound components is organised efficiently upon their arrival (Vernikos et al., 2014). Organising and assigning space to every group of components via a virtual space is more practical for organising the site in terms of accessibility to both the components and the relevant area of the site (Trani et al., 2015).

\subsubsection{Planning and scheduling}

The manufacturer, as a part of the project team, is linked to the other parties, not only in the main planning and scheduling of the project, but also in the case of any rapid changes. A collaborative environment and information-sharing platform for 'early decision-making' (Bank et al., 2010) is the main capability of BIM, 
playing a dominant role in both the main planning/scheduling phase, and any correction planning/rescheduling.

\subsubsection{Safety}

Under effective management of the activities in a BIM-OSM project, all activities are optimally organised and formulated, thereby reducing complexity, which results in fewer accidents. Modelling of the assembly of the prefabricated components in BIM enables contractors to review the erection and positioning process virtually, which may reveal any potential unobserved safety shortcomings (Irizarry et al., 2013). The likelihood of falls (Zhang et al., 2013) and collisions due to plants operations in OSM-based projects is high due to the dispatch and movement of components dispatch on the site. BIM is able to reveal the probable fall situations from heights, identify the best access routes for plant operations, and offer lifting drawings for crane activities, which will minimise the chances of reportable incidents (Zhang et al., 2010).

\subsubsection{Social sustainability}

BIM enables a constructive interaction between designers, manufacturers and contractors by offering accurate information in terms of the units' quality specifications and properties, which can be deemed as comfort in the professional life (Wong \& Fan, 2013). This reflects an easing in professional life, equivalent to social sustainability.

\subsubsection{Economic sustainability}

Flexibility in an OSM-based project is highly limited once the units are transferred to the construction site. Through the capability of clash detection and accurate data via BIM in an OSM-based project, the chance of any extra activities required for rework is limited. Since any rework comes with excessive use of workforce, equipment, plant and material removal and reuse, minimising the chance of rework satisfies the aspects of material waste as well as work hours (Wang and Chong, 2016).

\subsubsection{Environmental sustainability}

Material usage is more efficient and accurate in a controlled environment. On the basis of an exact quantity of material determined via BIM, both the chance of material waste and rework are minimised, satisfying environment sustainability requirements (Wang \& Chong, 2016). The construction site is more organised once the job shifts from the factory to the construction site. In fact, the workspace is more efficient due to the reduced number of activities required and the smaller workforce compared to a more congested traditional construction site. The need for fewer trades working at the same time results in less noise and less emissions from equipment. Reduced on-site activity also means more efficient energy consumption. Thus, it can be claimed that BIM is effective from the point of view of environmental sustainability (Wong \& Kuan, 2014).

\subsubsection{Interface management}

BIM provides a constant communication line with the other parties, including designers, construction contractors (Smith, 2014) and manufacturers that is accessible with no waiting time. Therefore, information and data are exchangeable with manufacturers, as parties involved in a project, in the form of readable formats consistent with BIM. 


\subsubsection{Procurement and contracts}

A BIM-based contract in an OSM-oriented project carries significant responsibility for the parties involved in meeting the project requirements, from data production to executive operations, as fragmentation between the design and delivery teams can be controlled at an early stage. No time is wasted on disputes to identify the party responsible in case of errors or failures, as the organisational structure is clear. Also, in the case of any changes, the manufacturer can be notified more rapidly due to the BIM information-sharing platform, and the production line can be immediately modified to take the steps required for the change because under a BIM model, the management of the drawing process and any technical review is more rapid than with other techniques (Barlish \& Sullivan, 2012). Thus, the determination of responsibility for faulty components can be managed within the contract.

\subsubsection{Information data flow through virtual model quality and data richness}

The capacity of BIM to provide transparent and accurate specifications, as well as to share data, enables the manufacturer to participate in the assembly guideline definition, indicating the exact procedures to position manufactured components. This capability originates from 'model quality and data richness' (Haron et al., 2010). It enables the manufacturer to efficiently recognise all the parts of a component for the purpose of assembly (Ezcan et al., 2013), which is important for contractors on the construction site. This confers simple accessibility and easy observation of data and thus an effective data flow (Lee, Eastman, \& Lee, 2015) between the designers, the contractors and the manufacturers. In addition, under BIM the ability to identify repetition enables designers and manufacturers to recognise more automation opportunities for 'series production', resulting in cost saving due to 'virtual object-oriented design' (Popov et al., 2010; Sacks et al., 2010).

\subsubsection{Value engineering}

The effect of changes to manufactured components (constructability) can be assessed under a BIM model, which also allows cost evaluations (Forgues et al., 2012) prior to any actions in the real project (feasibility via $\mathrm{VE}$ ). It can be claimed that VE is much more effective for VE than merely brainstorming via paperwork. Therefore, VE is achievable in a BIM-OSM-based project.

\subsubsection{Concurrent engineering}

Concurrent engineering has been introduced to the industry as one of the techniques able to reduce project process time through fast-tracking activities or running activities in parallel (Goulding et al., 2015). For example, the components may be produced while site preparation is in progress. Concurrent engineering is achievable within OSM-BIM projects on the assumption that any incompatibility of components would disturb the fast-tracking plan (running activities in parallel) in OSM-based projects. By providing the exact specifications for all components and continuous information-sharing and communication between the designer, contractor and manufacturer, the chances of on-site rework efforts to rectify or adjust components, as well as the chance of rejection of components, is minimised. Thus, the fast-tracking plan for concurrent engineering is not hindered in OSM-BIM projects. 


\section{Integrated Framework}

This research has highlighted the interactions between OSM and BIM and their contribution to construction performance in a broader sense, as well as to construction productivity in a narrow sense. It has justified each capability of OSM and BIM independently, as well as the capabilities of the concurrent application of OSM-BIM (OSM-BIM interactions), respectively. Figure 3 illustrates the integrated framework that leads to improved overall project performance. It consists of three stages: input, process and output. At the input stage, the data are derived from the capabilities of BIM and OSM that have the potential to interact with each other. It shows that the concurrent application of the capabilities that have the potential for OSM-BIM interactions (POBIs) can result in improved KPrIs, subject to their systematic adoption. Systematic adoption refers to the proper and concurrent practice of the techniques' capabilities at both the design and the construction stages. The improvement measures result in overall project performance. It is expected that construction professionals can improve project productivity by considering the 12 KPrIs through the interactions of BIM and OSM (as shown in process stage). The KPrIs may be addressed by interactions through the optimisation of the work breakdown structure at the design and construction stages. Subsequently, the technical specifications and contractual requirements can be formulated before the construction stage so that these interactions can be applied.

Low productivity has always been one of the main challenges for the stakeholders in the construction industry, particularly from the continuous improvement perspective. The proposed integrated framework provides useful references to the potential productivity areas that need to be targeted in a project, and which may help to achieve the highest level of project productivity and performance. It also promotes the effective adoption of BIM and OSM in the future. 


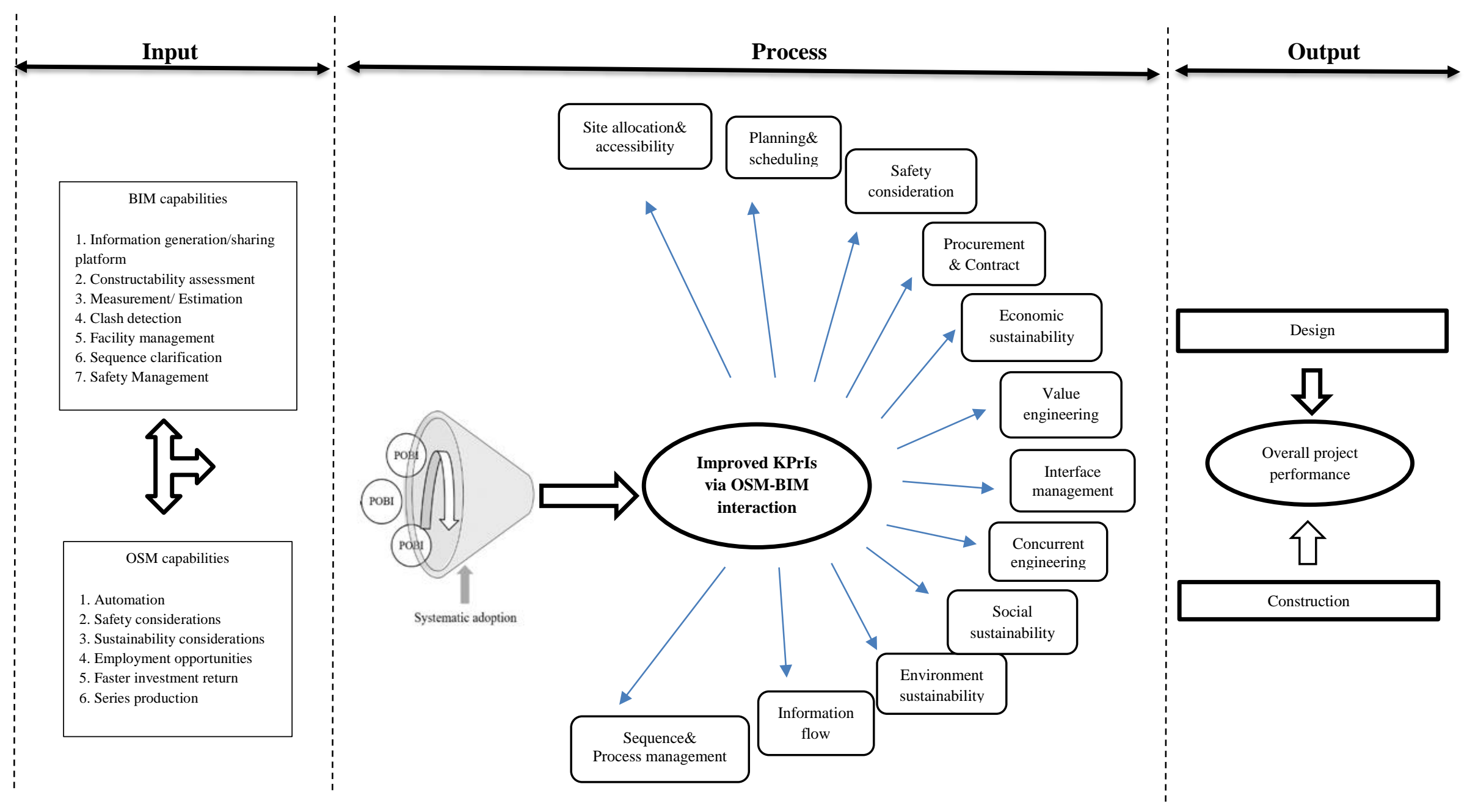

Figure 4. Integrated framework of OSM-BIM interactions for productivity improvement 


\section{Discussion and Conclusion}

This research project has critically reviewed the literature in order categorise KPrIs for construction projects, and identified the indicators that can potentially be used to improve productivity and performance via the capabilities of OSM and BIM, both independently and together. It has addressed seven BIM-based capabilities and six OSM-based capabilities individually, as well as 12 POBIs relevant for KPrIs improvement from the productivity perspective. A scoping review was used to identify these capabilities, and 100 journal articles were carefully analysed under four main research categories: construction productivity/performance, BIM in construction, OSM in construction and OSM-BIM interactions. This revealed the capabilities of the OSM and BIM techniques, and 12 potential interactions to achieve KPrIs improvement within ten categories: company characteristics, materials, labour, management, regulation, machinery, contract condition, information technology, engineering and external circumstances.

The main advances of this critical review paper are: (a) the first systematic discovery of the 12 potential interactions between OSM and BIM and their benefits in productivity improvement; and (b) the integrated framework that addresses KPrIs improvement at the design and construction stages. The related previous studies have only briefly discussed the integration of BIM and OSM at a preliminary stage of the building processes (Nawari, 2012), the management drivers (Vernikos et al., 2014), the required BIM functionalities (Ezcan et al., 2013), and the potential benefits (Goulding et al., 2012; Amanda et al., 2017). The identification of these interactions between BIM and OSM extends the existing body of knowledge, especially for the effective implementation and management of OSMBIM-based projects. The productivity indicators identified as useful for improvement by OSM and BIM can serve as a guideline and benchmark for organisations, which they can use to streamline their resources and operations to enable them to achieve the desired outcomes of their projects. Moreover, the findings of this paper are generalisable to both developed and developing countries.

However, certain limitations need to be considered, such as the exclusion of the latest publications in the proposed four research categories, the lack of empirical research in recognising the degree of impact and practicability of the OSM-BIM interactions, and for the prioritisation of each key productivity indicator. Future research could investigate the complex cause-effect relationships between BIM and OSM capabilities and their interaction. As a part of a larger research project, this paper will be followed by statistical analysis using Structural Equation Modelling (SEM) to reveal the degree of practicability of these interactions. A range of hypothesised interactions will be evaluated and judged by experienced practitioners. The results of these investigations will be applicable to improving the planning and managerial stages for productivity improvement in OSM-based projects. A case study would be complementary to the current research to evaluate the practicability of the interactions and to uncover potential barriers in the pathways of OSM-BIM-based projects.

\section{Acknowledgements}

The authors would like to acknowledge the contribution of an Australian Government Research Training Programme Scholarship and Australian Research Council (ARC) Discovery Project (DP170104612) supporting this research. 


\section{Refrences}

Amanda, F., Tah, J., \& Cheung, F. (2017), "BIM in off-site manufacturing for buildings", Journal of Building Engineering, Vol. 14, Nov, pp. 89-102.

Ahmad, T., \& Thaheem, M. J. (2018), "Economic Sustainability Assessment of Residential Buildings: A dedicated assessment framework and implications for BIM", Sustainable Cities and Society, Vol. 38, Apr, pp. 476-491.

Aliakbarlou, S., Wilkinson, S., \& Costello, S. B. (2018), "Rethinking client value within construction contracting services", International Journal of Managing Projects in Business, Vol. 11 No. 4, pp. 1007-1025.

Allmon, E., Haas, C. T., Borcherding, J. D., \& Goodrum, P. M. (2000), "US construction labor productivity trends, 1970-1998", Journal of construction engineering and management, Vol. 126 No. 2, pp. 97-104.

Arashpour, M., Wakefield, R., Blismas, N., \& Minas, J. (2015), "Optimization of process integration and multi-skilled resource utilization in off-site construction", Automation in Construction, Vol. 50, Feb, pp. 72-80.

Arditi, D., \& Mochtar, K. (2000), "Trends in productivity improvement in the US construction industry", Construction Management \& Economics, Vol. 18 No. 1, pp. 15-27.

Arif, M., Goulding, J., \& Rahimian, F. P. (2012), "Promoting off-site construction: Future challenges and opportunities", Journal of Architectural Engineering, Vol. 18 No. 2, pp. 75-78.

Azhar, S. (2011), "Building information modeling (BIM): Trends, benefits, risks, and challenges for the AEC industry", Leadership and management in engineering, Vol. 11 No. 3, pp. 241-252.

Azhar, S., Behringer, A., Sattineni, A., \& Mqsood, T. (2012), "BIM for facilitating construction safety planning and management at jobsites", Proceedings of the CIB-W099 International Conference: Modelling and Building Safety, 10-11 Sep, Singapore.

Azhar, S., Brown, J., \& Farooqui, R. (2009), "BIM-based sustainability analysis: An evaluation of building performance analysis software", Proceedings of the 45th ASC annual conference, 14 Apr, Florida.

Bank, L. C., McCarthy, M., Thompson, B. P., \& Menassa, C. C. (2010), "Integrating BIM with system dynamics as a decision-making framework for sustainable building design and operation", Proceedings of the First International Conference on Sustainable Urbanization (ICSU), 15-17 Dec, Hong Kong.

Barati, R., Charehzehi, A., \& Preece, C. N. (2013), "Enhancing planning and scheduling program by using benefits of BIM-based applications", Civil and Environmental Research, Vol, 3 No. 5, pp. $41-48$.

Barlish, K., \& Sullivan, K. (2012), "How to measure the benefits of BIM-A case study approach", Automation in Construction, Vol. 24, Jul, pp. 149-159.

Bassioni, H. A., Price, A. D., \& Hassan, T. M. (2004), "Performance measurement in construction", Journal of management in engineering, Vol. 20 No. 2, pp. 42-50.

Bi, X., \& Jia, X.-m. (2016), "Research on the Integration of Lean Construction and BIM and a Case Study in Shanghai Tower Project", Proceedings of the 6th International Asia Conference on Industrial Engineering and Management Innovation, Vol. 2, pp. 1027-1036, doi: org/10.2991/97894-6239-145-1_101. 
Blayse, A. M., \& Manley, K. (2004), "Key influences on construction innovation", Construction innovation, Vol. 4 No. 3, pp. 143-154.

Blismas, N. (2007), "Off-site manufacture in Australia: Current state and future directions", Brisbane, Australia, Cooperative Research Centre for Construction Innovation.

Blismas, N., Pasquire, C., \& Gibb, A. (2006), "Benefit evaluation for off-site production in construction", Construction Management and Economics, Vol. 24 No. 2, pp. 121-130.

Blismas, N., \& Wakefield, R. (2009), "Drivers, constraints and the future of offsite manufacture in Australia", Construction innovation, Vol. 9 No. 1, pp. 72-83.

Blismas, N. G., Pendlebury, M., Gibb, A., \& Pasquire, C. (2005), "Constraints to the use of off-site production on construction projects", Architectural Engineering and Design Management, Vol. 1 No. 3, pp. 153-162.

Bryde, D., Broquetas, M., \& Volm, J. M. (2013), "The project benefits of building information modelling (BIM)", International journal of project management, Vol. 31No. 7, pp. 971-980.

Boyd, N., Khalfan, M. M., \& Maqsood, T. (2012), "Off-site construction of apartment buildings", Journal of Architectural Engineering, Vol. 19 No. 1, pp. 51-57.

Chan, A. P., Scott, D., \& Chan, A. P. (2004), "Factors affecting the success of a construction project", Journal of construction engineering and management", Vol. 130 No. 1, pp. 153-155.

Chan, D. W., \& Kumaraswamy, M. M. (1995), "A study of the factors affecting construction durations in Hong Kong", Construction Management and Economics, Vol. 13 No. 4, pp. 319-333.

Chan, T. K. (2009), "Measuring performance of the Malaysian construction industry", Construction Management and Economics, Vol. 27 No. 12, pp. 1231-1244.

Charehzehi, A., Chai, C., Md Yusof, A., Chong, H.-Y., \& Loo, S. C. (2017), "Building information modeling in construction conflict management", International Journal of Engineering Business Management, Vol. 9, available at: https://doi.org/10.1177/ 1847979017746257.

Cheng, J. C., \& Lu, Q. (2015), "A review of the efforts and roles of the public sector for BIM adoption Worldwide", Journal of Information Technology in Construction (ITcon), Vol. 20, No. 27, pp. 442-478.

Chen, L., \& Luo, H. (2014), "A BIM-based construction quality management model and its applications", Automation in Construction, Vol. 46, Oct, pp. 64-73.

Chong, Lee, C.-Y., \& Wang, X. (2017), "A mixed review of the adoption of Building Information Modelling (BIM) for sustainability", Journal of cleaner production, Vol, 142, pp. 4114-4126, doi: 10.1016/j.jclepro.2016.09.222.

Chong, H.-Y., Preece, C., \& Rogers, J. (2014), "BIM update 2013: A mixed review approach from academia and industry", Trends and Development in Management Studies, Vol. 3 No. 1, pp. 1-21.

Chong, H.-Y., \& Wang, X. (2016), "The outlook of building information modeling for sustainable development", Clean Technologies and Environmental Policy, Vol. 18 No. 6, pp. 1877-1887.

Chong, H. Y., Lopez, R., Wang, J., Wang, X., \& Zhao, Z. (2016), "Comparative analysis on the adoption and use of BIM in road infrastructure projects", Journal of Management in Engineering, Vol. 32 No. 6, doi: 10.1061/ (ASCE) ME.1943-5479.0000460.

Ciribini, A. L. C., Bolpagni, M., \& Oliveri, E. (2015), "An innovative approach to e-public tendering based on Model Checking", Procedia Economics and Finance, Vol. 21, pp. 32-39, available at: https://doi.org/10.1016/S2212-5671 (15)00147-1. 
Comin, D. (2010), "Total factor productivity", Economic Growth, In Durlauf S.N., Blume L.E. (eds), London, pp.260-263, available at: https://doi.org/10.1057/9780230280823_32

Cox, R. F., Issa, R. R., \& Ahrens, D. (2003), "Management's perception of key performance indicators for construction", Journal of construction engineering and management, Vol. 129 No. 2, pp. 142-151.

Diamantopoulos, A., \& Winklhofer, H. M. (2001), "Index construction with formative indicators: An alternative to scale development", Journal of marketing research, Vol. 38 No. 2, pp. 269-277.

Ding, L., Zhou, Y., \& Akinci, B. (2014), "Building Information Modeling (BIM) application framework: The process of expanding from 3D to computable nD", Automation in Construction, Vol. 46, Oct, pp. 82-93.

Wang, J., W. Sun, W. Shou, X. Wang, C. Wu, H.-Y. Chong, Y. Liu and C. Sun (2015), "Integrating BIM and LiDAR for real-time construction quality control." Journal of Intelligent \& Robotic Systems, Vol. 79 No. 3-4, pp. 417-432.

Dozzi, S. P., \& AbouRizk, S. M. (1993), "Productivity in construction: Institute for Research in Construction", Ottawa, Ontario, National Research Council Ottawa.

Eastman, C. M., \& Sacks, R. (2008), "Relative productivity in the AEC industries in the United States for on-site and off-site activities", Journal of construction engineering and management, Vol. 134 No. 7, pp. 517-526.

Elnaas, H., Gidado, K., \& Philip, A. (2014), "Factors and drivers effecting the decision of using off-site manufacturing (OSM) systems in house building industry", Journal of Engineering, Project, and Production Management, Vol. 4 No. 1, pp. 51-58.

Enshassi, A., Kochendoerfer, B., \& Abed, K. (2013), "Trends in productivity improvement in construction projects in Palestine", Revista ingeniería de construcción, Vol. 28 No. 2, pp. 173-206.

Ezcan, V., Isikdag, U., \& Goulding, J. (2013), "BIM and off-site manufacturing: recent research and opportunities", Proceedings of the 19th CIB World Building Congress, 05-09 May, Brisbane, Australia.

Ferrada, X., \& Serpell, A. (2013), "Using organizational knowledge for the selection of construction methods", International Journal of Managing Projects in Business, Vol. 6 No. 3, pp. 604-614.

Forgues, D., Iordanova, I., Valdivesio, F., \& Staub-French, S. (2012). Rethinking the cost estimating process through 5D BIM: A case study. Proceedings of the Construction Research Congress 2012: Construction Challenges in a Flat World, May 21-23, West Lafayette, Indiana.

Gade, R. J. (2016), "A Proposed Solution to the Problem of Construction Industry Overruns: Lean Construction Techniques and Linear Programming", Indian Journal of Science and Technology, Vol. 9 No. 25, doi: 10.17485/ijst/2016/ v9i25/91929.

Ganah, A., \& John, G. A. (2014), “Achieving Level 2 BIM by 2016 in the UK”, In Computing in Civil and Building Engineering, Vol. 2014, pp. 143-150.

Ghazali, W., \& Irsyad, W. A. (2016), "Potential of building information modelling (BIM) in improving safety management in the Malaysian construction industry", Master's thesis, Universiti Tun Hussein Onn, Malaysia.

Goulding, J. S., Pour-rahimian, F., Arif, M., \& Sharp, M. (2012), "Offsite construction: strategic priorities for shaping the future research agenda", Journal of Architectonic. ca, Vol. 1 No. 1, pp. 62-73. 
Goulding, J. S., Pour Rahimian, F., Arif, M., \& Sharp, M. (2015), "New offsite production and business models in construction: priorities for the future research agenda", Architectural Engineering and Design Management, Vol. 11 No. 3, pp. 163-184.

Hamdi, O., \& Leite, F. (2012), "BIM and Lean interactions from the bim capability maturity model perspective: A case study", Proceedings of the IGLC 2012-20th Conference of the International Group for Lean Construction, The International Group for Lean Construction, 18-20 Jul, San Diego.

Haron, A., Marshall-Ponting, A., \& Aouad, G. (2010), "Building information modelling: Literature review on model to determine the level of uptake by the organization", Proceedings of the Proceedings of the CIB World Building Congress 2010, 10-13 May, Salford, UK.

Hasan, A., Baroudi, B., Elmualim, A., \& Rameezdeen, R. (2018). Factors affecting construction productivity: a 30 year systematic review. Engineering, Construction and Architectural Management, Vol. 25 No. 7, pp.916-937.

Hergunsel, M. F. (2011), "Benefits of building information modeling for construction managers and BIM based scheduling", Master's thesis, Worcester Polytechnic Institute, Massachusetts.

Hjelmbrekke, H., Klakegg, O. J., \& Lohne, J. (2017), "Governing value creation in construction project: a new model", International Journal of Managing Projects in Business, Vol.10 No. 1, pp. 60-83.

Huang, A. L., Chapman, R. E., \& Butry, D. T. (2009), "Metrics and tools for measuring construction productivity: Technical and empirical considerations, Report No. 1109", Maryland, U.S. Department of Commerce National Institute of Standards and Technology.

Irizarry, J., Karan, E. P., \& Jalaei, F. (2013), "Integrating BIM and GIS to improve the visual monitoring of construction supply chain management", Automation in Construction, Vol. 31, May, pp. 241-254.

Kang, J. H., Anderson, S. D., \& Clayton, M. J. (2007), "Empirical study on the merit of web-based $4 \mathrm{D}$ visualization in collaborative construction planning and scheduling", Journal of construction engineering and management, Vol. 133 No. 6, pp. 447-461.

Kapelko, M., Horta, I. M., Camanho, A., \& Lansink, A. O. (2015), "Measurement of input-specific productivity growth with an application to the construction industry in Spain and Portugal", International Journal of Production Economics, Vol. 166, Aug, pp. 64-71.

Khalfan, M., \& Maqsood, T. (2014), "Current state of off-site manufacturing in Australian and Chinese residential construction", Journal of Construction Engineering, Vol. 2014, available at: http://dx.doi.org/10.1155/2014/164863.

Khoshnava, S., Ahankoob, A., Preece, C., \& Rostami, R. (2012), "Application of BIM in construction safety", Proceedings of the Management in Construction Research Association (MiCRA), 05-06 Dec, Kuala Lumpur, Malaysia.

Khosrowshahi, F., \& Arayici, Y. (2012), "Roadmap for implementation of BIM in the UK construction Industry", Engineering, Construction and Architectural Management, Vol. 19, No.6, pp. 610-635.

Lee, Y.-C., Eastman, C. M., \& Lee, J.-K. (2015), "Validations for ensuring the interoperability of data exchange of a building information model", Automation in Construction, Vol. 58, Oct, pp. 176-195.

Lessing, J., Stehn, L., \& Ekholm, A. (2005), "Industrialized housing: definition and categorization of the concept", Proceedings of the Annual conference of the International Group for Lean Construction, 19-21 Jul 2005. pp 471-480. 
Li, J., Hou, L., Wang, X., Wang, J., Guo, J., Zhang, S., \& Jiao, Y. (2014), "A project-based quantification of BIM benefits", International Journal of Advanced Robotic Systems, Vol. 11 No. 8, doi: $10.5772 / 58448$.

Love, P. E., Edwards, D. J., Han, S., \& Goh, Y. M. (2011), "Design error reduction: toward the effective utilization of building information modeling", Research in Engineering Design, Vol. 22 No. 3, pp. 173-187.

Lu, N., \& Korman, T. (2010), "Implementation of building information modeling (BIM) in modular construction: Benefits and challenges", Proceedings of the Construction Research Congress 2010: Innovation for Reshaping Construction Practice, 8-10 May, Alberta, Canada.

Lu, Y., Wu, Z., Chang, R., \& Li, Y. (2017), "Building Information Modeling (BIM) for green buildings: A critical review and future directions", Automation in Construction, Vol. 83, pp. 134148, available at: https//doi.org/10.1016/j.autcon.2017.08.024.

Meiling, J., Backlund, F., \& Johnsson, H. (2012), "Managing for continuous improvement in offsite construction: Evaluation of lean management principles", Engineering, Construction and Architectural Management, Vol. 19 No. 2, pp. 141-158.

Meng, X. (2012), "The effect of relationship management on project performance in construction", International journal of project management, Vol. 30 No. 2, pp. 188-198.

Moghadam, M., Alwisy, A., \& Al-Hussein, M. (2012), "Integrated BIM/Lean base production line schedule model for modular construction manufacturing", Proceedings of the Construction Research Congress 2012: Construction Challenges in a Flat World, May 21-23, West Lafayette, Indiana.

Murray, M. (2003), "Rethinking construction: the egan report (1998)", Oxford, UK, Blackwell Science.

Nawari, N. O. (2012), "BIM standard in off-site construction", Journal of Architectural Engineering, Vol. 18 No. 2, pp. 107-113.

Newton, K., \& Chileshe, N. (2012), "Awareness, Usage and Benefits of Building Information Modelling (BIM) Adoption-The Case of the South Australian Construction Organizations", Proceeding of the 28th ARCOM Conference, 03-05 Sep, Edinburg, Scotland.

Olofsson, T., Lee, G., Eastman, C., \& Reed, D. (2007), "Benefits and lessons learned of implementing building virtual design and construction (VDC) technologies for coordination of mechanical, electrical, and plumbing", Journal of information technology in construction, Vol. 13, pp. 324-342, available at: http//www.itcon.org/2008/22.

Pan, W., Gibb, A. G., \& Dainty, A. R. (2012), "Strategies for integrating the use of off-site production technologies in house building", Journal of construction engineering and management, Vol. 138 No. 11, pp. 1331-1340.

Park, C.-S., Kim, H.-J., Park, H.-T., Goh, J.-H., \& Pedro, A. (2017), "BIM-based idea bank for managing value engineering ideas", International journal of project management, Vol. 35 No. 4, pp. 699-713.

Pham, M. T., Rajić, A., Greig, J. D., Sargeant, J. M., Papadopoulos, A., \& McEwen, S. A. (2014). A scoping review of scoping reviews: advancing the approach and enhancing the consistency. Research synthesis methods, 5(4), 371-385.

Pasquire, C. L., \& Connolly, G. E. (2002), "Leaner construction through off-site manufacturing", Proceedings IGLC-10, Aug, Gramado, Brazil.

Pellinen, P. (2016), "Developing design process management in BIM based project involving infrastructure and construction engineering", Master's thesis, Aalto University, Finland. 
Peters, M. D., Godfrey, C. M., Khalil, H., McInerney, P., Parker, D., \& Soares, C. B. (2015). Guidance for conducting systematic scoping reviews. International journal of evidence-based healthcare, 13(3), 141-146.

Poirier, E. A., Staub-French, S., \& Forgues, D. (2015), "Measuring the impact of BIM on labor productivity in a small specialty contracting enterprise through action-research", Automation in Construction, Vol. 58, pp. 74-84, available at: http//doi.org/10.1016/j.autcon.2015.07.002.

Popov, V., Juocevicius, V., Migilinskas, D., Ustinovichius, L., \& Mikalauskas, S. (2010), "The use of a virtual building design and construction model for developing an effective project concept in 5D environment", Automation in Construction, Vol. 19 No. 3, pp. 357-367.

Porwal, A., \& Hewage, K. N. (2013), "Building Information Modeling (BIM) partnering framework for public construction projects", Automation in Construction, Vol. 31, pp. 204-214.

Sacks, R., Dave, B., Koskela, L., \& Owen, R. (2009), "Analysis framework for the interaction between lean construction and building information modelling", Journal of construction engineering and management, Vol. 136 No. 9, pp. 968-980.

Sacks, R., Koskela, L., Dave, B. A., \& Owen, R. (2010), "Interaction of lean and building information modeling in construction", Journal of construction engineering and management, Vol. 136 No. 9, pp. 968-980.

SBEnrc (2017), "Accelerating the Mainstreaming of Building Manufacture in Australia, Final industry report Project 1.42", Perth, Western Australia, Sustainable Built Environment National Research Center.

Shin, J. Kim, I and Choi, J (2016), "BIM-based Work Environment of Value Engineering in Sustainable Construction", Advanced Science and Technology Letters, Vol. 141, pp. 79-83, available at: http://dx.doi.org/10.14257/astl.2016.141.16.

Segerstedt, A., \& Olofsson, T. (2010), "Supply chains in the construction industry", Supply Chain Management: An International Journal, Vol. 15 No. 5, pp. 347-353.

Smith, P. (2014), "BIM implementation-global strategies", Procedia Engineering, Vol. 85, pp. 482492, doi: 10.1016/j.proeng.2014.10.575.

Succar, B. (2009), "Building information modelling framework: A research and delivery foundation for industry stakeholders", Automation in Construction, Vol. 18 No. 3, pp. 357-375.

Sulankivi, K., Kähkönen, K., Mäkelä, T., \& Kiviniemi, M. (2010), "4D-BIM for construction safety planning", Proceedings of W099-Special Track 18th CIB World Building Congress, 10-13 May, Salford, UK.

Takim, R., \& Akintoye, A. (2002), "Performance indicators for successful construction project performance", American Journal of Civil Engineering and Architecture, Vol. 2 No. 2, pp. 77-82.

Trani, M. L., Cassano, M., Todaro, D., \& Bossi, B. (2015), "BIM level of detail for construction site design", Procedia Engineering, Vol. 123, pp. 581-589, doi: 10.1016/j.proeng.2015.10.111.

Vernikos, V. K., Goodier, C. I., Broyd, T. W., Robery, P. C., \& Gibb, A. G. (2014), "Building information modelling and its effect on off-site construction in UK civil engineering", Proceedings of the institution of civil engineering-Management, Procurement and Law, Vol. 167 No. 3, pp. 152159.

Walker, D. (2018), "Integrating Project Delivery", International Journal of Managing Projects in Business, Vol. 11 No. 2, pp. 548-554.

Wang, X., \& Chong, H.-Y. (2016), "Setting new trends of integrated Building Information Modelling (BIM) for construction industry", Construction innovation, Vol. 15 No. 1, pp. 2-6. 
Wang, X., \& Love, P. E. (2012), "BIM+ AR: Onsite information sharing and communication via advanced visualization", Proceedings of the Computer Supported Cooperative Work in Design (CSCWD), 23-25 May, Wuhan, China.

Wong, J. K.-W., \& Kuan, K.-L. (2014), "Implementing 'BEAM Plus' for BIM-based sustainability analysis", Automation in Construction, Vol. 44, pp. 163-175, doi: 10.1016/j.autcon.2014.04.003.

Wong, K.-d., \& Fan, Q. (2013), "Building information modelling (BIM) for sustainable building design", Facilities, Vol. 31 No. 3/4, pp. 138-157.

Wynn, M. T., Ouyang, C., Low, W. Z., Kanjanabootra, S., Harfield, T., \& Kenley, R. (2013), "A process-oriented approach to supporting Off-site Manufacture in construction projects", Proceedings of the International council for research and innovation in building and construction (CIB), 05-09 May, Brisbane, Australia.

Zhang, C., AlBahnassi, H., \& Hammad, A. (2010), "Improving construction safety through realtime motion planning of cranes", Proceedings of the International Conference on Computing in Civil and Building Engineering, June 30- July 02, Natingham, UK.

Zhang, S., Teizer, J., Lee, J.-K., Eastman, C. M., \& Venugopal, M. (2013), "Building information modeling (BIM) and safety: Automatic safety checking of construction models and schedules", Automation in Construction, Vol. 29, pp. 183-195, available at:http//doi.org/10.1016/j.autcon.2012.05.006. 
https://doi.org/10.1108/IJMPB-08-2018-0168 https://creativecommons.org/licenses/by/4.0/ 